\title{
Dependence of Mathematical Errors on Mathematical Thinking Style
}

\section{Залежність виникнення математичних помилок від мисленнєвого математичного стилю}

\author{
Lidiia Moiseienko \\ Dr. in Psychology, Professor of the Department of Higher Ma- \\ thematics, Ivano-Frankivsk National Technical University of Oil and \\ Gas, Ivano-Frankivsk (Ukraine) \\ ORCID ID: https://orcid.org/0000-0001-9288-7355 \\ Researcher ID: http://www.researcherid.com/rid/X-7506-2018 \\ E-mail: Lmoyseyenko@i.ua
}

\section{Лідія Мойсеєнко}

Доктор психологічних наук, професор кафедри вищої математики, Івано-Франківський національний технічний університет нафти і газу, м. Івано-Франківськ (Україна)

\section{Liubov Shehda}

Ph.D. in Physics and Mathematics, Assistant Professor of the Department of Higher Mathematics, Ivano-Frankivsk National Technical University of Oil and Gas, Ivano-Frankivsk (Ukraine)

ORCID ID: https://orcid.org/0000-0003-4721-7832

Researcher ID: http://www.researcherid.com/rid/Z-2516-2019

E-mail: shegda.luba@gmail.com

\section{Любов Шегда}

Кандидат фізико-математичних наук, доцент кафедри вищої математики, Івано-Франківський національний технічний університет нафти і газу, м. Івано-Франківськ (Україна)

Address for correspondence, e-mail: kpnu_lab_ps@ukr.net Copyright: (c) Moiseienko Lidiia, Shehda Liubov

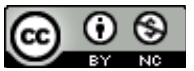
The article is licensed under CC BY-NC 4.0 International (https://creativecommons.org/licenses/by-nc/4.0/)

(C) Moiseienko Lidiia, Shehda Liubov

DOI (article): https://doi.org/10.32626/2227-6246.2021-54.116-136 http://journals.uran.ua/index.php/2227-6246 
DOI: https://doi.org/10.32626/2227-6246.2021-54

2021. ВИПУСК 54

The contribution of the author: Moiseienko L. $-60 \%$, Shehda L. $-40 \%$.

Авторський внесок: Мойсеєнко Л. $-60 \%$, Шегда Л. $-40 \%$.

\section{ABSTRACT}

The results of research of creative mathematical thinking have been analyzed and the expediency of studying its individual differences through the analysis of mental styles of solving mathematical problems has been stated.

The aim of the article is to identify the reasons of students' mathematical errors and to analyze the influence of mathematical thinking style on the reasons and sense of mathematical errors in the process of solving creative mathematical tasks.

To identify and determine the essence of mathematical thinking styles, the method of analysis of search actions of subjects during the solution of mathematical problems of different classes was used.

The results of the research. It is stated that mathematical thinking style is a holistic system of interconnected actions, by means of which the mental mathematical result is achieved.

It has been found that mental errors occurred at all stages of the search process of students with different mathematical thinking styles. Differences in mathematical thinking styles become the basis of the content of errors. There are three groups of causes of mental errors: ignorance, low-quality analogy, irrelevance of links. Different influence of ignorance on the search actions of students with different styles of mathematical thinking is proved.

It is stated that the introduction of low-quality analogy in different styles of mathematical thinking is different in content. It was found that the irrelevance of references and conclusions has a different nature in the thinking of students with different thinking mathematical styles.

Conclusions. Thinking style is manifested throughout the process of solving a mathematical problem, provides a different content of the search process, through which a positive mathematical result is achieved or leads to mental errors.

Key words: creative mathematical thinking, mathematical thinking styles, mathematical errors. 


\section{Introduction}

Psychological researches (Huang, 2013; Fatemi, 2016; Keşan \& Kaya, 2018) prove that mathematical thinking, producing a mathematical result, makes mistakes. Such researches complement the holistic view of the creative mathematical process and expand the possibility of influencing the thinking of mathematicians through the leveling of psychological factors that cause erroneous results.

Mathematical errors occur on the way of mental search movement from condition to solution, in the process of mental operation of mathematical facts. The falsity of a mental mathematical step can be determined by the content of the result: violation of the truth of mathematical statements, the impossibility of further application of the obtained result, incorrect solution, etc.

It should be noted that the study of creative mathematical thinking is a study of the thinking process aimed at solving creative mathematical problems, that is those which don't have ready-made solution algorithms in mathematics, or which are not known to the solver (Moreno-Armella, Hegedus \& Kaput, 2008). The emphasis in solving the problem is on finding a sequence of thought steps, rather than determining the finished result - the answer (even if it is correct) (Jaleel \& Titus, 2015; Shahbari \& Daher, 2016).

In addition, the creative mathematical result must be evaluated in a categorical-alternative sense: the statement is true or not. (This cannot be justified in a number of other forms of creativity). Mathematical results can only be true (under certain conditions) or false (under certain conditions). Those who operate on them must take into account their nature and conditions of authenticity (Schoenfeld, 1992).

Mental activity is always personally and individually unique. The essence of individual-personal differences in the process of thinking of a particular person is in the ability to record certain processes selectively and in the production of (C) Moiseienko Lidiia, Shehda Liubov

DOI (article): https://doi.org/10.32626/2227-6246.2021-54.116-136 
DOI: https://doi.org/10.32626/2227-6246.2021-54

2021. випуск 54

selective mental actions. Individual differences in search activities aimed at solving a new problem are manifested in the ability to see the problem situation, in the formulation of the problem for themselves, in particularity of the analysis and use of task conditions, in the ratio of conscious and unconscious, in the emotional regulation of search etc.

Recognizing the presence of certain individual traits in the thought process, researchers note that they provide the individual uniqueness of intellectual activity that is inherent in each individual in particular (Kholodnaia, 2002; Perminov, 2009).

Style occupies a boundary position between the individual and the environment, because it is both an invention of a man and a means of any activity aimed at transforming the environment (style of drawing, style of writing, style of cognition, etc.). This creates a basis for the study of human style or through the study of its individuality, or through the study of the features of the activity in the process of which this style arose. These approaches have been implemented in psychology (Zhang \& Zhua, 2011; Fatemi, 2016).

Based on various individual and personal characteristics, scientists divide the human thought process into types: practical and theoretical, empirical and theoretical, productive and reproductive. Recently, scientists have turned their attention to clarifying the individual style of activity as an integral concept that provides information about the individual-personal particularity of activity (Wojciechowicz, 1999; Perminov, 1999; Kholodnaia, 2002).

As for mathematical thinking, in the literature there is also a selection of its various individual and personal characteristics and its division into species, types, on such grounds. They include, for example, the division into «algebraists» and «geometers», «logicians» and «intuitionists», «those who make discoveries» and «those who use mathematics for applied purposes» .

(C) Moiseienko Lidiia, Shehda Liubov

DOI (article): https://doi.org/10.32626/2227-6246.2021-54.116-136 
DOI: https://doi.org/10.32626/2227-6246.2021-54

2021. випуск 54

Considering mathematical style as mathematical handwriting, an individual feature of a person who solves a mathematical problem, we, at one time, identified three styles of creative mathematical thinking (integral, differential and integral-differential) (Moiseienko, 2003). This helped us to penetrate deeper into the procedural and dynamic content of creative thinking and more. In this article, we will analyze the nature of mathematical errors that are associated with different thinking styles of students who have solved mathematical problems. The study of the dependence of the causes of mental errors on the mathematical thinking style in solving various mathematical problems is an important component of the problem of elucidating the psychological essence of creative mathematical thinking.

The purpose of the article is: to analyze the nature of the dependence of mathematical errors of different types on three styles of creative mathematical thinking: integral, differential and integral-differential.

The task of the article is: to identify mental errors of creative mathematical thinking and classify them by cause and to find out the essence of the influence of thinking mathematical style on the content of erroneous conclusions in the process of solving creative mathematical problems.

\section{Methods of the research}

The method of research is the analysis of students' search actions during the solution of creative mathematical problems of different classes.

That is, using the problem method of research, we have developed 23 series of mathematical problems, so that each series contributes to the study of a particular aspect of mathematical thinking. A total of 160 tasks have been used. All problems, regardless of the series, have been divided by the nature of the requirement for the problem into 4 classes of problems: prob(C) Moiseienko Lidiia, Shehda Liubov

DOI (article): https://doi.org/10.32626/2227-6246.2021-54.116-136 
DOI: https://doi.org/10.32626/2227-6246.2021-54

2021. випуск 54

lems for finding an unknown quantity, problems for proof, problems for construction and heuristic problems.

We have conducted an experimental study of creative mathematical thinking of students of Ivano-Frankivsk National Technical University of Oil and Gas. 100 students have taken part in the experiment. Each student has solved 10 different math problems from different classes.

The tasks have been performed by each student in the presence of the experimenter. The work has been carried out individually. The student has been given the opportunity to work independently, there have been no direct instructions on how to solve the problem. The tasks have not been limited to a certain time.

Firstly, to identify the mathematical thinking styles of the students under study, we have analyzed the search process in solving three specially selected problems. These have been multifaceted tasks that contain hidden problems (Moiseienko \& Shehda, 2021). They have provided several solutions based on various generalized schemes that reflect the meaning of the problem. In solving these problems, thinking is based on logical, numerical and spatial components. In addition, solving them involves guesswork. Analysis of such aspects of thinking is the basis for differentiating mathematical thinking by style.

The causes of students' mental errors in the process of solving the problems have been studied and attention has been focused on the analysis of the influence of stylistic differences in mental process of students of the technical university on these reasons.

\section{Results and discussions}

According to the analysis of solving three specially selected problems, it has been identified that students have three mathematical thinking styles: integral, differential, integral-differential. We should note that mathematical thinking of almost all students has been attributed to one of these three styles.

(c) Moiseienko Lidiia, Shehda Liubov DOI (article): https://doi.org/10.32626/2227-6246.2021-54.116-136 
DOI: https://doi.org/10.32626/2227-6246.2021-54

2021. випуск 54

The thinking process of students with a differential style consists in a detailed study of the condition of the problem: separation of structural elements, study of their properties and relations, production and testing of numerous hypotheses. As a result, structural elements acquire different operational meanings, which incline the subject to various mathematical actions, often at random. However, this contributes to an indepth study of the problem situation. The initial idea of the solution in the differential style of mathematical thinking arises as a conscious result of intellectual activity, a little later in the form of a reference problem. Logical steps are encrusted with conjectures, which, in turn, speed up the search, but the idea of a solution is formed from the original concept consciously and systematically.

Students with integral thinking style have fundamentally different perception of the problem. For them, the problem is a holistic system of mathematical objects with certain already functioning properties. The students introduce into the problem only some of potentially possible properties of the components of mathematical elements. That is, the structural elements immediately generate a specific operational meaning, which determines the direction of the search and ensures the emergence of conjecture, which arises suddenly in the initial stages. It combines some of the structural elements of the problem and mathematical knowledge associated with those elements, creating a specific model of the problem situation. The content of such guess is often to reconstruct the components, to abandon the traditional vision of the problem. Henceforward, the guess is investigated (confirmed or refuted) using known logical techniques within the current model. Hypotheses that arise in the subsequent search process relate to me thods of logical substantiation of conjecture. That is, in integral mathematical thinking style, the primary concept of a solution arises unconsciously, but is formed into a solution by means of systematic conscious thought steps.

(C) Moiseienko Lidiia, Shehda Liubov

DOI (article): https://doi.org/10.32626/2227-6246.2021-54.116-136 
The perception of the problem by students with differential-integral style is ambiguous. It may happen that at first the problem for them is a set of different mathematical objects as for the students with differential style of mathematical thinking, or a holistic system as for the students with integral thinking, but after a certain period of time, they change this primary vision of the problem to another. This change occurs repeatedly. Mathematical thinking of the representatives of the differential-integral style, at the same time relies on standard logical steps and innovative techniques. Accordingly, the search process can begin with both conjecture and traditional logical steps. Different structural elements of the problem are activated in different ways: some are associated with one specific operational meaning, others - with several of them. In case of the subjective advantage of a «single-operation" element, it is this element who directs the search in a certain way. If this advantage was not found, the students continued to study the structural elements, linking them to other operational meanings. And in the process of developing one way of the solution, another one, which is sometimes quite distant from the first, may suddenly appear. Such a change is made easily, without a noticeable attachment to initiated algorithmic actions, or to actions based on the guess. Therefore, in differential-integral style of mathematical thinking, the primary concept of the solution may arise as an unconscious product of thought, or as a result of conscious thinking. But it is not a sign of the functioning of a clear model of the problem situation described by the mathematical problem. Such a model usually does not exist, but there are several options that could potentially be the basis for its creation.

The effectiveness of search actions of the selected groups of students by the styles of mathematical thinking was statistically the same.

We state that students with different mathematical thinking styles made mental errors at all stages of their search 
process. They were based on errors of various cognitive processes (attention, imagination, memory, etc.), emotional state, psychological properties of the person who solved the problem. We have identified three groups of causes of mental errors: ignorance, low-quality analogy, irrelevance of references.

Ignorance. This is one of the most obvious reasons for erroneous conclusions. In the absence or insufficiency of mathematical knowledge and experience, the student cannot create a complete picture described by the problem; cannot detect all existing connections between structural elements, find out their properties. Conclusions made in such an information-constrained environment are often wrong. Ignorance itself leads to incomplete comparison. It may not just be about ignorance of a theorem or formula. For example, the use of verbal constructions «not more than», «none», «does not exceed», «at least one», etc. implies their clear mathematical meaning. Failure to comply with it led to production of defective consequences of mathematical statements, which, in turn, gave rise to mathematical errors.

Low-quality analogy. The use of analogy is one of the basic skills of thinking, the basis of understanding anything. However, the analogue can be misused and cause erroneous conclusions. We observed analogies only in appearance, without penetrating the essence and transferring the known one to new conditions by insignificant parameters.

Another low-quality analogy is associative influence. It is known that if two events occur close in time or space, then on the basis of the formed connection, a person, when one of them occurs, expects the other. The same is when solving mathematical problems: if from a subjective point of view a particular problem, or a part of it, seems similar to the known, then the one who solves it, transfers the elements of the known problem to a new one, without noticing a significant difference between them. Associative influence, as the basis of erroneous conclusions, has been most often observed in the study.

(C) Moiseienko Lidiia, Shehda Liubov

DOI (article): https://doi.org/10.32626/2227-6246.2021-54.116-136 
When solving mathematical problems, there are erroneous conclusions, which are based on the use of an analogue on the principle: "We have always done in such a way". In this case, the veiled nuances of the problem are not revealed. They are retouched by the emerging guidelines of the problem and provoke conclusions without taking into account such nuances.

Often, subjects solving mathematical problems deliberately ignore some of the information in the problem. In fact, we are not talking about those cases when something was not noticed, but about the deliberate manipulation of a new problem situation under the existing standard solution by neglecting information, or supplementing the problem with additional information.

Irrelevance of references and conclusions. Wrong conclusions from specific conditions, irrelevance of references in forming a conclusion are another reason for errors in mathematical thinking. In particular, we observed mental inferences about the causal relationship between two mathematical statements, which is made only on the basis of following one of them, or their coexistence (false cause). Otherwise, we recorded the wrong ratio of the whole and its parts.

Sometimes students, when solving a mathematical problem, allow its simplification: they don't solve in a general form, but giving a specific meaning to the unknown (easing the contradictions) items. Meanwhile it is not stated that this is only a partial case, and that the student, for example, cannot cope with the general one. That is, we are talking about those cases when the result is accompanied by a subjective belief in the validity of the solution found for this problem, and the falsity of conclusions and references is not noticed.

Another example of irrelevance of references and conclusions is the «unjustified dichotomy». As you know, in mathematics, you can often say "yes» or "no" to the statements. This is the reason why some of the respondents to a number of questions, which were formulated as follows: «Does it exist ...»

(C) Moiseienko Lidiia, Shehda Liubov DOI (article): https://doi.org/10.32626/2227-6246.2021-54.116-136 
DOI: https://doi.org/10.32626/2227-6246.2021-54

2021. випуск 54

«Can it be ...», considered the solution to be the answer: «yes» or «no». Subjectively, they formed the task of choosing one of the two possible options - this was the content of their solution. In fact, those tasks had a much deeper meaning and provided much more possible options.

The cases we have called the «vicious circle» are interesting. In this case, the condition becomes a reformulated conclusion, and the structural scheme of the argument resembled a circle, where the conclusion is based on the reformulated conclusion. For example, when solving the problem of the possibility of drawing a plane through 4 points, the following reasoning was recorded: "Once we draw a plane, then under this condition, it will be possible to draw it» .

We analyzed the mistakes made by students with three styles of creative mathematical thinking that we had previously singled out. We should note that we observed all kinds of errors in search activities of students of all styles of mathematical thinking. The quantitative calibration of errors caused in different ways is given in Fig. 1.

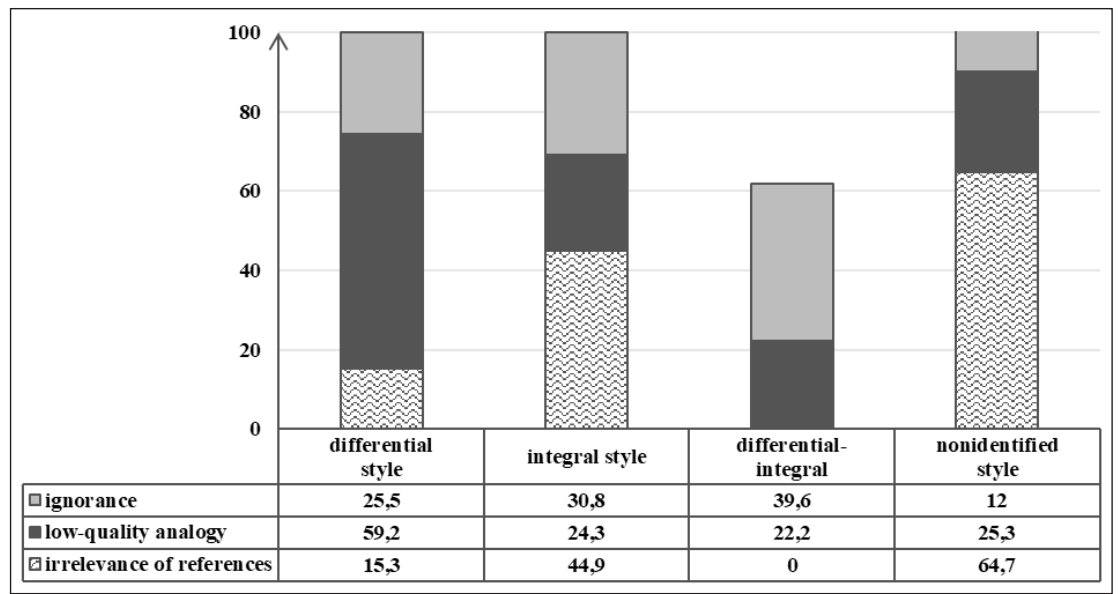

Fig. 1. Dependence of the type of errors on the mathematical thinking style

(C) Moiseienko Lidiia, Shehda Liubov

DOI (article): https://doi.org/10.32626/2227-6246.2021-54.116-136 
DOI: https://doi.org/10.32626/2227-6246.2021-54

2021. випуск 54

Despite the different number of errors of the same type that took place in the mathematical thinking of students with different styles, it is necessary to emphasize their different qualitative content.

Ignorance. If the absence or lack of knowledge and experience does not allow all students to create a complete picture described by the problem, then this state of affairs does not equally affect the search activities of students with different styles of mathematical thinking. For this reason, students with differential mathematical thinking do not correctly identify all the existing connections between the structural elements and find out their properties. This suspends their search for a long time, does not allow forming a successful solution hypothesis. Their hypotheses resemble the expressions «If..., then».

Students with integral style consciously «fit» unknown facts of the problem (those who do not know). Under any circumstances, they seek to formulate a hypothesis for the solution, and later to find out the unknown item. Their hypotheses are based on an inner conviction in a certain direction of further search actions, and on the thought that unknown knowledge will contribute to their chosen direction of finding a solution. They often rely on incorrect mathematical facts, guessing the false properties of mathematical objects, but those that support their chosen hypothesis.

Students with differential-integral mathematical thinking, after finding out the impossibility to use certain structural elements due to ignorance, try to neglect them and solve the problem without them, that is to form a hypothesis without some of the components of the problem, which are given by the condition. When they fail, they re-study the condition of the problem, skipping what they do not know. We mean the conscious rejection of information that is not supported by knowledge.

Low-quality analogy. We often observed incorrect use of analogues in the search actions of students with integral

(C) Moiseienko Lidiia, Shehda Liubov DOI (article): https://doi.org/10.32626/2227-6246.2021-54.116-136 
DOI: https://doi.org/10.32626/2227-6246.2021-54

2021. випуск 54

thinking style. Their desire to formulate a solution hypothesis quickly led to the use of an inferior analogue, an analogue by insignificant parameters. Students with differential mathematical thinking style almost did not assume this. After all, before making a hypothesis, they thoroughly study the structural elements of the problem, discover their various properties and connections. In mental activity of students with differential-integral style of mathematical thinking at the intermediate stage of solving the structural elements are not thoroughly studied. Therefore, they often have the wrong use of analogues, but these students often abandon such analogues in further work on the problem.

Most often the basis of erroneous conclusion was associative influence. In this case, mental actions of students with different styles did not differ. But the use of the analogue on the principle: "We have always done so» was more typical for the students with integral mathematical thinking style.

Conscious ignoring some information is also interesting. This is not about rejecting information that falls out of the student's mathematical knowledge system. We focus on discarding of pieces of information as unnecessary. It should be noted that this is not always wrong when solving mathematical problems (there are problems with redundant or missing information). We analyze mental errors when solving problems that did not contain redundant information. It is noted that students with differential mathematical thinking style more often rejected «unnecessary» information, and students with integral style added «missing» data in the condition of the problem. Students with differential-integral style of mathematical thinking acted in two ways.

Irrelevance of references and conclusions. More often we observed errors of this type in search actions of students with differential-integral thinking style. However, in content, they differed significantly among the carriers of the three defined styles. In differential style, students more often used (c) Moiseienko Lidiia, Shehda Liubov

DOI (article): https://doi.org/10.32626/2227-6246.2021-54.116-136 
DOI: https://doi.org/10.32626/2227-6246.2021-54

2021. випуск 54

the wrong ratio of the whole and its parts, and in integral style - simplification: the conscious solving the problem not in general, but giving the unknown a specific meaning (easing the contradiction). Meanwhile, the first group does not recognize (for some time) that this is only a partial case, and the second group consciously insists on the accuracy of the result. Students with differential-integral thinking style were more likely to have an unjustified dichotomy, or a vicious circle. By hypothesizing that a "yes» (or «no») answer should be given, or by accepting the requirement of the problem as a condition, they tried to find confirmation of this by studying in detail the structural elements of the problem and their connections.

It was not possible to give a differentiated description of the causes of errors made by the students whose mathematical thinking was not attributed to these three styles.

The causes of students' mathematical thinking errors were also self-confidence, emotional state. However, we do not consider them in this article.

\section{Conclusions}

The creative mathematical thinking style is an individual characteristic of students' search process in solving creative mathematical problems. It is stable to various problem situations and is manifested in self-regulation of mathematical search process; in individual control, evaluation and correction of the decision-maker's own actions. The phenomenon of mathematical style is also manifested in the nature of mental errors. Differences in mathematical thinking styles by nature of the flow of mental actions, by place and role of unconscious mental acts become the basis of the content of errors. Having distinguished three styles (differential, integral, differentialintegral), we can state different influence of ignorance on students' search actions.

For students with differential mathematical thinking style, who base their actions primarily on logical steps, igno-

(c) Moiseienko Lidiia, Shehda Liubov DOI (article): https://doi.org/10.32626/2227-6246.2021-54.116-136 
DOI: https://doi.org/10.32626/2227-6246.2021-54

2021. випУСК 54

rance leads to ineffective solution hypotheses and often to incorrect solutions. They are less likely than others to misuse analogues, but often allow the wrong ratio of the whole and its parts, consider some information in the problem superfluous. Their desire for a comprehensive (often unjustified) study of structural elements distracts attention, does not lead to the selection of the main problem, and thus its misunderstanding and inability to form a correct solution hypothesis. Students with integral style, who often produce solving hypotheses unconsciously, supplement the lack of knowledge with partially correct mathematical facts, which also leads to incorrect solutions. Students with differential-integral mathematical thinking deliberately reject information that is not known.

Students with different mathematical thinking styles use analogues in different ways. Incorrect use of analogues by insignificant parameters is more often observed in search actions of students with integral thinking style, which is manifested in easing the contradiction inherent in the condition of the problem, in addition of the "missing" information. The analogy made in this way often becomes the basis of the project of the solution and receives subjective belief in its correctness. Students with differential mathematical thinking style use analogues by insignificant parameters much less, however, they more often consider some information in the problem superfluous. In mental activity of students with differentialintegral style it is also common to misuse analogues, but these students are more likely to abandon such analogues in further work on the problem.

The irrelevance of references and conclusions was more often observed in search actions of students with differentialintegral thinking style and was manifested in the use of unjustified dichotomy. Students with differential style more often used the wrong ratio of the whole and its parts, not recognizing the partial meaning of the problem, and students with (C) Moiseienko Lidiia, Shehda Liubov

DOI (article): https://doi.org/10.32626/2227-6246.2021-54.116-136 
integral style used simplification, accompanied by conscious belief in the accuracy of the result.

It was not possible to give a differentiated description of the causes of errors made by the students whose mathematical thinking was not attributed to these three styles.

The prospect of further research on this problem is to study the means of psychological influence on the creative mathematical thinking of people with different mathematical styles to avoid mental errors.

\section{Literature}

Войцехович В.Э. Господствующие стили математического мышления. Стили в мателатике: социокультурная философия лателати$\kappa и$ / под ред. А.Г. Барабашова. Санкт-Петербург : РХГИ, 1999. С. 495-505.

Мойсеєнко Л.А. Психологія творчого математичного мислення: монографія. Івано-Франківськ : Факел, 2003. 481 с.

Моляко В.А. Творческая конструктология (пролегомены). Киев : Освита Украины, 2007. 388 с.

Перминов В.Я. Априорность и реальная значимость исходных представлений математики. Стили в математике: социокультурная философия лателатики / под ред. А.Г. Барабашова. Санкт-Петербург : РХГИ, 1999. С. 80-100.

Султанова Л.Б. Роль интуиции и неявного знания в формировании стиля математического мышления. Стили в мателатике: социокультурная философия лателатики / под ред. А.Г. Барабашова. Санкт-Петербург : РХГИ, 1999. С. 66-106.

Холодная М.А. Психология интеллекта. Парадоксы исследования. Санкт-Петербург : Питер, 2002. 272 с.

Borromeo, F.R. Mathematical thinking styles in school and across cultures. In S. Cho (Eds.). Selected regular lectures from the 12 th International Congress on Mathematical Education. Springer, 2015, 153-173. URL : https://doi.org/10.1007/978-3-319-17187-69.

Fatemi, M. Relationship between thinking styles and academic achievement of the students. International Journal of Humanities and Cultural Studies, 2016, 2 (4), 1353-1361.

Huang, C.-H. Engineering students' visual thinking of the concept of definite integral. Global Journal of Engineering Education, 2013, 15 (2), 111-117.

(C) Moiseienko Lidiia, Shehda Liubov

DOI (article): https://doi.org/10.32626/2227-6246.2021-54.116-136 
DOI: https://doi.org/10.32626/2227-6246.2021-54

2021. випУск 54

Jaleel, S., \& Titus, B. Effectiveness of Gaming Strategy on Mathematical Creativity of Students at Secondary Level. Indian Journal of Applied Research, 2015, 5 (10), 243-245. DOI 10.15373/2249555X.

Keşan, C., \& Kaya, D. Mathematics and science self-efficacy resources as the predictor of academic success. International Online Journal of Educational Sciences, 2018, 10 (2), 45-58.

Moiseienko, L., \& Shehda, L. Thinking styles of Understanding Creative Mathematical Problems in the Process of Solving. Збірник наукових праць «Проблеми сучасної психологї», 2021, 51, 142-164. DOI https://doi.org/10.32626/2227-6246.2021-51.142-164.

Moreno-Armella, L., Hegedus, S.J., \& Kaput, J.J. From static to dynamic mathematics: Historical and representational perspectives. Educational Studies in Mathematics, 2008, 99-111. DOI 10.1007/s 10649008-9116-6.

Ortiz, Enrique. The Problem-Solving Process in a Mathematics Classroom. Transformations, 2016, 1 (1), 257-289.

Shahbari, J.A., \& Daher, W. Mathematical models' features: Technology and non-technology. European Journal of Science and Mathematics Education, 2016, 4 (4), 523-533.

Schoenfeld, A.H. Learning to think mathematically: Problem solving, metacognition, and sense-making in mathematics. Handbook for Research on Mathematics Teaching and Learning. New York : MacMillan, 1992. P. 334-370.

Yaftian, N. The outlook of the Mathematicians' Creative Processes. Procedia. Social and Behavioural Sciences, 2015, 191, 2515-2519. URL : https://www.journals.elsevier.com/procedia-social-and-behavioral-sciences/special-issues.

Zhang, L.F., Zhua, C. Thinking styles and conceptions of creativity among university students. Journal of Educational Psychology, 2011, 31 (3), 361-375.

\section{References}

Voitsekhovich, V.E. (1999). Gospodstvuiushchiie stili matematicheskogo myshleniia [Dominant styles of mathematical thinking]. Stili $v \mathrm{ma}^{-}$ tematike: sotsiokulturnaia filosofiia matematiki - Styles in mathematics: sociocultural philosophy of mathematics, (pp. 495-505). Sankt-Peterburg : RKhGI [in Russian].

Moiseienko, L.A. (2003). Psykholohiia tvorchoho matematychnoho myslennia. [Psychology of creative mathematical thinking]. Ivano-Frankivsk : Fakel [in Ukrainian].

(C) Moiseienko Lidiia, Shehda Liubov

DOI (article): https://doi.org/10.32626/2227-6246.2021-54.116-136 http://journals.uran.ua/index.php/2227-6246 
Moliako, V.A. (2007). Tvorcheskaia konstruktologiia (prolegomeny) [Creative Constructology]. Kiiev : Osvita Ukrainy [in Ukrainian].

Perminov, V.Ya. (1999). Apriornost i realnaia znachimost iskhodnykh predstavlenii matematiki [A priory and real significance of the original concepts of mathematics]. Stili v matematike: sotsiokulturnaia filosofiia matematiki - Styles in mathematics: sociocultural philosophy of mathematics, (pp. 80-100). Sankt-Peterburg : RKhGI [in Russian].

Sultanova, L.B. (1999). Rol intuitsii i neiavnogo znaniia $v$ formirovanii stilia matematicheskogo myshleniia [The role of intuition and tacit knowledge in the formation of the style of mathematical thinking]. Stili $v$ matematike: sotsiokulturnaia filosofiia matematiki - Styles in mathematics: sociocultural philosophy of mathematics, (pp. 66-76). Sankt-Peterburg : RKhGI [in Russian].

Kholodnaia, M.A. (2002). Psikhologiia intellekta. Paradoksy issledovaniia [The psychology of intelligence. Research paradoxes]. Sankt-Peterburg : Piter [in Russian].

Borromeo, F.R. (2015). Mathematical thinking styles in school and across cultures. In S. Cho (Eds.). Selected regular lectures from the $12^{\text {th }}$ International Congress on Mathematical Education, (pp. 153-173). Springer. Retrieved from https://doi.org/10.1007/978-3-319-17187-69.

Fatemi, M. (2016). Relationship between thinking styles and academic achievement of the students. International Journal of Humanities and Cultural Studies, 2 (4), 1353-1361.

Huang, C.-H. (2013). Engineering students' visual thinking of the concept of definite integral. Global Journal of Engineering Education, 1 (2), 111-117.

Jaleel, S., \& Titus, B. (2015). Effectiveness of Gaming Strategy on Mathematical Creativity of Students at Secondary Level. Indian Journal of Applied Research, 5 (10), 243-245. Retrieved from 10.15373/ $22249555 \mathrm{X}$.

Keşan, C., \& Kaya, D. (2018). Mathematics and science self-efficacy resources as the predictor of academic success. International Online Journal of Educational Sciences, 10 (2), 45-58.

Moiseienko, L., \& Shehda, L. (2021). Thinking styles of Understanding Creative Mathematical Problems in the Process of Solving. Zbirnyk naukovykh prats "Problemy suchasnoi psykholohii» - Collection of research papers, 51, 142-164. Retrieved from https://doi.org/ 10.32626/2227-6246.2021-51.142-164.

Moreno-Armella, L., Hegedus, S.J., \& Kaput, J.J. (2008). From static to dynamic mathematics: Historical and representational perspectives.

(C) Moiseienko Lidiia, Shehda Liubov

DOI (article): https://doi.org/10.32626/2227-6246.2021-54.116-136 
DOI: https://doi.org/10.32626/2227-6246.2021-54

2021. випуск 54

Educational Studies in Mathematics, (pp. 99-111). Retrieved from 10.1007/s10649-008-9116-6.

Ortiz, Enrique (2016). The Problem-Solving Process in a Mathematics Classroom. Transformations, 1 (1), 257-289.

Schoenfeld, A.H. (1992). Learning to think mathematically: Problem solving, metacognition, and sense-making in mathematics. Handbook for Research on Mathematics Teaching and Learning, (pp. 334-370). Nju Jork : MakMillan.

Shahbari, J.A., \& Daher, W. (2016). Mathematical models' features: Technology and non-technology. European Journal of Science and Mathematics Education, 4 (4), 523-533.

Yaftian, N. (2015). The outlook of the Mathematicians' Creative Processes. Procedia. Social and Behavioural Sciences, 191, 2515-2519. Retrieved from https://www.journals.elsevier.com/procediasocial-and-behavioral-sciences/special-issues.

Zhang, L.F., \& Zhua, C. (2011). Thinking styles and conceptions of creativity among university students. Journal of Educational Psychology, 31 (3), 361-375.

Мойсеєнко Лідія, Шегда Любов. Залежність виникнення математичних помилок від мисленнєвого математичного стилю

\section{АНОТАЦІЯ}

Mета cmammi - виявити причини виникнення математичних помилок у студентів, проаналізувати вплив математичного мисленнєвого стилю на причини виникнення та зміст математичних помилок у прочесі розв'язування творчих математичних задач студентами.

Для розв'язання поставлених у роботі завдань використано такий теоретичний метод дослідження: аналіз пошукових дій суб'єктів упродовж розв'язування творчих математичних задач різних класів.

Результати дослідження. Проаналізовано результати досліджень творчого математичного мислення й констатовано доцільність вивчення причин виникнення мисленнєвих помилок шляхом аналізу мисленнєвих стилів розв'язування творчих математичних задач. Визначено, що мисленнєвий математичний стиль - цілісна система взаємопов'язаних дій, за допомогою яких досягається мисленнєвий математичний резульmam.

Установлено, що мисленнєві помилки виникали на всіх етапах пошукового процесу в студентів із різними мисленнєвими математичними (C) Moiseienko Lidiia, Shehda Liubov

DOI (article): https://doi.org/10.32626/2227-6246.2021-54.116-136 http://journals.uran.ua/index.php/2227-6246 
DOI: https://doi.org/10.32626/2227-6246.2021-54

2021. вИПУСК 54

стилями. Відмінності математичних мисленнєвих стилів стали основою змісту помилок. Виокремлено три групи причин виникнення мисленнєвих помилок: незнання, неякісна аналогія, нерелевантність посилань. Доведено різний вплив незнань на пошукові дії студентів із різним стилем математичного мислення.

Призначено різне за змістом упровадження неякісного аналогізування при різних стилях математичного мислення. 3’ясовано, що нерелевантність посилань і висновків має різний характер у мисленнєвій діяльності студентів із різними мисленнєвими математичними стилями.

Висновки. Мисленнєвий математичний стиль проявляється впродовж усього процесу розв'язування математичної задачі, забезпечує різний зміст пошукового процесу, за допомогою якого досягається позитивний математичний результат, що призводить до мисленнєвих помилок.

Ключові слова: творче математичне мислення, мисленнєві стилі математичного мислення, математичні помилки.

Мойсеенко Лидия, Шегда Любовь. Зависимость возникновения математических ошибок от мыслительного математического стиля

\section{АННОТАЦИЯ}

Цель статьи - выявить причины возникновения ошибок у студентов, проанализировать влияние математического мыслительного стиля на причины возникновения и содержание ошибок в прочессе решения творческих математических задач.

Для решения поставленных в работе задач использован следующий теоретический метод исследования: анализ поисковых действий субъектов на протяжении решения творческих математических задач разных классов.

Результаты исследования. Проанализированы результаты исследований творческого математического мышления и констатировано целесообразность изучения причин возникновения ошибок, используя анализ мыслительных стилей решения творческих математических задач.

Определено, что мыслительный математический стиль - это целостная система взаимосвязанных действий, с помощью которых достигается математический результат. Установлено, что мыслительные ошибки возникают на всех этапах поискового процесса у студентов

(C) Moiseienko Lidiia, Shehda Liubov DOI (article): https://doi.org/10.32626/2227-6246.2021-54.116-136 
DOI: https://doi.org/10.32626/2227-6246.2021-54

2021. випуск 54

с разными мыслительными математическими стилями. Отличие математических мыслительных стилей стало основанием содержания ошибок. Выделено три группы причин возникновения мыслительных ошибок: незнание, некачественная аналогия, нерелевантность ссылок. Доказано разное влияние незнаний на поисковые действия студентов с разными стилями математического мышления. Предназначено разное по содержанию внедрение некачественного анализирования при разных стилях математического мышления. Установлено, что нерелевантность ссылок и выводов имеет разный характер в мыслительной деятельности студентов с разными стилями математического мышления.

Выводы. Мыслительный математический стиль проявляется на протяжении всего процесса решения математической задачи, обеспечивая разное содержание поискового процесса, с помощью которого достигается как позитивный математический результат, так и образуются мыслительные ошибки.

Ключевые слова: творческое математическое мышление, мыслительные стили математического мышления, математические ошибки.

Original manuscript received August 27, 2021 Revised manuscript accepted October 02, 2021

(C) Moiseienko Lidiia, Shehda Liubov

DOI (article): https://doi.org/10.32626/2227-6246.2021-54.116-136 http://journals.uran.ua/index.php/2227-6246 